\title{
RNAseq analysis of bronchial epithelial cells to identify COPD-associated genes and SNPS
}

Jiyoun Yeo ${ }^{1}$, Diego A. Morales², Tian Chen³ ${ }^{3}$ Erin L. Crawford², Xiaolu Zhang ${ }^{4}$, Thomas M. Blomquist', Albert M. Levin ${ }^{5}$, Pierre P. Massion', Douglas A. Arenberg ${ }^{7}$, David E. Midthun ${ }^{8}$, Peter J. Mazzone ${ }^{9}$, Steven D. Nathan ${ }^{10}$, Ronald J. Wainz ${ }^{11}$, Patrick Nana-Sinkam ${ }^{12,13}$, Paige F. S. Willey ${ }^{14}$, Taylor J. Arend ${ }^{15}$, Karanbir Padda ${ }^{16}$, Shuhao Qiu ${ }^{17}$, Alexei Federov ${ }^{3,4}$, Dawn-Alita R. Hernandez ${ }^{18}$, Jeffrey R. Hammersley ${ }^{18}$, Youngsook Yoon ${ }^{18}$, Fadi Safi ${ }^{18}$, Sadik A. Khuder ${ }^{18}$ and James C. Willey ${ }^{19^{*}}$

\begin{abstract}
Background: There is a need for more powerful methods to identify low-effect SNPs that contribute to hereditary COPD pathogenesis. We hypothesized that SNPs contributing to COPD risk through cis-regulatory effects are enriched in genes comprised by bronchial epithelial cell (BEC) expression patterns associated with COPD.

Methods: To test this hypothesis, normal BEC specimens were obtained by bronchoscopy from 60 subjects: 30 subjects with COPD defined by spirometry (FEV1/FVC < 0.7, FEV1\% < 80\%), and 30 non-COPD controls. Targeted next generation sequencing was used to measure total and allele-specific expression of 35 genes in genome maintenance (GM) genes pathways linked to COPD pathogenesis, including seven TP53 and CEBP transcription factor family members. Shrinkage linear discriminant analysis (SLDA) was used to identify COPD-classification models. COPD GWAS were queried for putative cis-regulatory SNPs in the targeted genes.
\end{abstract}

Results: On a network basis, TP53 and CEBP transcription factor pathway gene pair network connections, including key DNA repair gene ERCC5, were significantly different in COPD subjects (e.g., Wilcoxon rank sum test for closeness, $p$-value $=5.0 \mathrm{E}-11$ ). ERCC5 SNP rs4150275 association with chronic bronchitis was identified in a set of Lung Health Study (LHS) COPD GWAS SNPs restricted to those in putative regulatory regions within the targeted genes, and this association was validated in the COPDgene non-hispanic white (NHW) GWAS. ERCC5 SNP rs4150275 is linked $\left(D^{\prime}=1\right)$ to ERCC5 SNP rs17655 which displayed differential allelic expression (DAE) in BEC and is an expression quantitative trait locus (eQTL) in lung tissue $(p=3.2 \mathrm{E}-7)$. SNPs in linkage $\left(\mathrm{D}^{\prime}=1\right)$ with rs 17655 were predicted to alter miRNA binding (rs873601). A classifier model that comprised gene features CAT, CEBPG, GPX1, KEAP1, TP73, and XPA had pooled 10-fold cross-validation receiver operator characteristic area under the curve of 75.4\% (95\% Cl: 66.3\%-89.3\%). The prevalence of DAE was higher than expected ( $p=0.0023)$ in the classifier genes.

Conclusions: GM genes comprised by COPD-associated BEC expression patterns were enriched for SNPs with cisregulatory function, including a putative cis-rSNP in ERCC5 that was associated with COPD risk. These findings support additional total and allele-specific expression analysis of gene pathways with high prior likelihood for involvement in COPD pathogenesis.

Keywords: COPD, eQTL, cis-regulation, GWAS, ERCC5, CAT, CEBPG, GPX1, KEAP1, TP73, XPA, Bronchial epithelial cells

\footnotetext{
* Correspondence: james.willey2@utoledo.edu

${ }^{19}$ Division of Pulmonary and Critical Care Medicine, Department of Medicine,

The University of Toledo College of Medicine, 3000 Arlington Avenue,

Toledo, $\mathrm{OH} 43614$, USA

Full list of author information is available at the end of the article
} International License (http://creativecommons.org/licenses/by/4.0/), which permits unrestricted use, distribution, and reproduction in any medium, provided you give appropriate credit to the original author(s) and the source, provide a link to the Creative Commons license, and indicate if changes were made. The Creative Commons Public Domain Dedication waiver (http://creativecommons.org/publicdomain/zero/1.0/) applies to the data made available in this article, unless otherwise stated. 


\section{Background}

Tobacco smoking is the predominant exogenous risk factor for chronic obstructive pulmonary disease (COPD) [1]. However, not all smokers develop COPD, implying that genetic factors contribute to COPD predisposition and pathogenesis. COPD genome-wide association studies (GWAS) have significantly increased our understanding of COPD pathogenesis, yet genomic variants identified through GWAS still explain only a small fraction of hereditary risk [2]. Each variant identified by COPD GWAS required large sample size for detection due to small effect on heritability $[3,4]$. Those that remain to be discovered will likely have an even lower effect. To address this challenge, one recent study was designed to discover rare coding variants with large effect on COPD risk, similar to that of alpha-1-antitrypsin deficiency [5]. In another approach, GWAS metaanalyses were used to identify common SNPs with very low effect through very large sample size $[3,6,7]$.

The purpose of this study was to identify candidate COPD-risk variants through their role in generation of COPD-associated transcript abundance patterns in bronchial epithelial cells (BEC). BEC coat the surfaces of lung airways and protect lung tissue from the environment. Sub-optimal BEC function is implicated in COPD pathogenesis [8-10]. We hypothesized that hereditary risk for COPD is due to the combined effect of multiple regulatory SNPs that each contribute to generation of BEC transcript abundance patterns associated with hereditary predisposition to COPD. If the proposed hypothesis is correct, a) a study to identify COPD-associated transcript abundance patterns in BEC will have high power and require a relatively small sample size, and b) genes comprised by such patterns will be enriched for cis-regulatory (r) SNPs and possibly SNPs significant in COPD GWAS using reduced stringency correction for multiple testing. Recent knowledge regarding predisposition for diseases caused by complex genetics supports this hypothesis in that SNPs associated with COPD and other complex phenotypes are enriched for cis- and/or transregulatory function [11-19]. For example, in a report on the recently updated GTEx database nearly $50 \%$ of common GWAS variants of interest were significantly associated with the expression of one or more genes $(P<$ 0.05 , after correcting for multiple tissue testing) [17].

A common way to identify cis-rSNPs is to measure dose effect of alleles at candidate cis-rSNPs on total expression [17]. SNPs significant by this analysis are referred to as cis-expression quantitative trait loci (eQTL). Another way to identify cis-rSNPs is by measurement of allele-specific expression (ASE) to identify differential allelic expression (DAE) [15, 20, 21]. Importantly, with appropriate methodological conditions, the power to identify cis-regulatory SNPs by measurement of ASE is higher than that for measurement of total expression [22], possibly because ASE controls for variation in trans-effects, including those resulting from variation in the environment. Importantly, there is a high correlation between cis-rSNPs identified by ASE measurement and those identified by as e-QTL by total expression [17]. The recent increase in throughput and reduction in cost of next generation sequencing (NGS) now facilitates large-scale measurement of ASE Tools and best practices for data processing in allelic expression analysis $[19,23]$.

We used targeted NGS technology to measure total and allele-specific expression (ASE) of 35 selected genome maintenance (GM) genes through RNA sequencing (RNAseq) of BEC RNA from 30 COPD subjects and 30 non-COPD controls. This targeted NGS method employs multiplex competitive PCR-amplicon libraries that provide excellent sequencing depth for all target analytes [24]. This approach is based on RT-PCR technology proven to ensure optimal quality-control characteristics, including high linear dynamic range, signal-to-analyte response, precision, and accuracy, and high correlation with qPCR [24-33].

The targeted NGS RNAseq method used in this study simplified allele-specific transcript abundance measurement and assessment of genes for cis-regulatory (r) SNPs manifesting as DAE. Gene expression is welldocumented to be a heritable trait [34-36]. Heritable differences in gene expression between individuals are caused by DNA variants that affect the expression level of one allele (cis-acting) or both alleles (trans-acting) of a gene [37]. Measurement of DAE is recognized as a powerful approach for identifying cis-acting regulatory variation [27, 35, 38]. We applied this technology to assess cis-rSNP activity and disease association at the exon level. As previously reported, multivariate exon-level analysis provides a more powerful approach than univariate gene-level analysis for identification of cis-rSNPs as well as disease association [39].

The 35 genes selected for analysis have a high prior likelihood for a role in COPD pathogenesis based on studies from this laboratory as well as those from other investigators. They represent antioxidant (AO), DNA repair (DNAR), and cell cycle control (CCC) pathways that play a key role in protecting BEC from inhaled cigarette smoke and toxins from the environment or occupational exposure [8, 25, 27, 29, 30, 40-43]. Importantly, there is significant inter-individual variation in $\mathrm{BEC}$ regulation of these key GM pathway genes [30, 40, 44, 45] and many function differently in BEC of COPD subjects compared to matched controls [8, 41-43, 46-54]. For example, genetic variants in CAT, GSTM1, GSTT1, GSTP1, SOD3, NFE2L2, KEAP1, OGG1, XRCC1, XRCC3, XRCC4, XRCC5, CDKN1A, and p53 are reported to be 
associated with COPD [54-69]. Further, regulation of both CEBP and TP53 family genes as well as many of their targets is different in subjects with COPD [52, 53, 67, 70].

A focus on members of the CEBP transcription factor family (i.e., CEBPA, CEBPD and CEBPG) and TP53 transcription factor family (i.e. TP53, TP63, and TP73) was based on evidence that they play an important role in regulating lung development and differentiation, and regulation of $\mathrm{AO}, \mathrm{DNAR}$, and $\mathrm{CCC}$ genes in BEC [25, $29,30,52,71-77]$. CEBPG is a truncated transcription factor that does not trans-activate but plays a regulatory role through heterodimer formation [78]. CEBPG regulates key GM genes in $\operatorname{BEC}[25,29,30]$. CEBPA and CEBPE are anti-proliferative transcription factors that lead to cell differentiation [71, 72, 78]. CEBPB and CEBPD contribute to regulation of cell-cycle progression [73-75]. CEBPG or CEBPA knockout mice die at birth or in adulthood respectively from emphysematous lungs $[52,76]$, providing experimental confirmation of the important role that sub-optimal function of these regulatory pathways plays in risk for COPD. The role of the TP53 gene transcription factor family in COPD is supported by association of TP53 and CDKN1A alleles with COPD risk and the role of CDKN1A in response to cigarette smoke $[66,67,79]$. TP63 plays a key role in airway epithelial cell proliferation and differentiation [8088], and is important in maintaining airway epithelial integrity and repair [89]. TP53 and TP73 work together to differentiate BEC into ciliated cells, and TP73 knockout in mice is associated with epithelial cell loss and inflammation of epithelium [90].

\section{Methods}

The goal of this study was to identify BEC gene expression patterns and hereditary DNA variants associated with COPD pathogenesis. Toward this goal we conducted a nested case-control study to a) identify genes associated with COPD based on BEC transcript abundance values and b) assess COPD-associated genes for cis-rSNP enrichment, measured as DAE. In parallel, we queried COPD GWAS for significance of putative cisrSNPs in COPD-associated genes. The study design is presented schematically in Fig. 1.

\section{Study subjects and biospecimens}

Homogeneous BEC biospecimens were obtained by bronchoscopic brush biopsy of normal appearing airway (main bronchus) epithelium from 30 COPD and 30 nonCOPD control subjects who were enrolled in the Lung Cancer Risk Test (LCRT) study (NCT 01130285 at Clinicaltrials.gov) [91]. The purpose of the LCRT study is to assess clinical validity of the previously reported LCRT to predict risk for lung cancer [25]. LCRT enrollment criteria included high demographic risk for lung cancer (age 50 or more and 20 pack-years smoking or more) and absence of lung cancer at time of enrollment based on chest CT. Summary statistics for the demographic and clinical characteristics of the subjects used in studies presented here are provided in Table 1 and information for each subject are provided in Additional file 1: Table S1 rows 3-12. Additional relevant details of the LCRT study are provided in Additional file 2. In the study presented here, COPD was defined by spirometry as FEV1/ FVC $<0.7$ and FEV1\% expected $<80 \%$. This corresponds to GOLD Stage II-IV COPD [92]. The LCRT enrolled 385 subjects at 11 clinical centers between 2011 and 2013. At each site, BEC were collected into ice-cold normal saline, then pelleted at $300 \mathrm{~g}$ and suspended in RNAlater. Biospecimens collected from each LCRT subject were shipped on dry ice overnight to ResearchDx, Irvine, CA, USA) for RNA extraction and storage. All subjects provided written informed consent. Use of tissue samples and corresponding medical/demographic data for this study is approved under UT IRB protocols

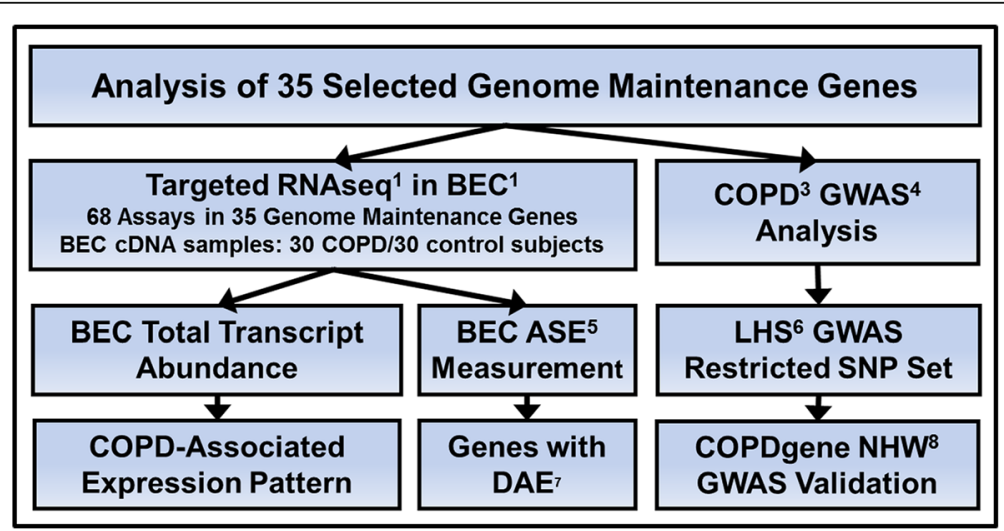

Fig. 1 Schematic description of research design. ${ }^{1}$ RNAseq: RNA sequencing by next generation sequencing; ${ }^{2} \mathrm{BEC}$ : bronchial epithelial cell; ${ }^{3} \mathrm{COPD}$, chronic obstructive pulmonary disease; ${ }^{4}$ GWAS, genome wide association study; ${ }^{5}$ ASE: allele-specific expression; ${ }^{6}$ LHS GWAS: Lung Health Study Genome Wide Association Study; ${ }^{7}$ DAE: differential allelic expression; ${ }^{8}$ COPDgene NHW: COPDgene Non-Hispanic White Cohort 
Table 1 Clinical characteristics of study population

\begin{tabular}{llll}
\hline & Non-COPD $(n=30)$ & COPD $(n=30)$ & $p$-value \\
\hline Age, yr & 64.3 & 63.6 & 0.713 \\
Sex & & & 0.009 \\
$\quad$ Male & 11 & 22 & \\
$\quad$ Female & 19 & 8 & 1.0 \\
Smoking status & & & \\
$\quad$ Current & 10 & 9 & \\
Former & 20 & 21 & 0.088 \\
$\quad$ Never & 0 & 0 & $5.81 \mathrm{E}-13$ \\
Pack-years & 49 & 60 & \\
FEV1/FVC & 0.81 & 0.53 & \\
Ethnicity & & & \\
White & 28 & 26 & \\
AA & 2 & 4 &
\end{tabular}

${ }^{\dagger} p$-values were calculated using Student's t-test for age and Pack-years, and Fisher exact test for sex and smoking history

\#108538 and \#107844. For this study, COPD and control subjects were selected with a goal to match for age, smoking history, and gender.

\section{BEC and peripheral blood cell (PBC) samples for} differential allelic expression (DAE) measurement

Reliable measurement of DAE required a sample size large enough to include a sufficient number of heterozygotes. Thus, in addition to the BEC samples and matched PBC samples from 60 LCRT subjects used in COPD classifier development, we evaluated archival BEC (120) and PBC (117) samples from additional subjects who were not characterized for COPD status for the purpose of DAE analysis. Of the total $180 \mathrm{BEC}$ and 177 PBC samples, matched samples were available from 98 subjects.

Summary statistics for the cohort used in allelespecific expression analysis are provided in Additional file 1: Table S2.

\section{RNA and DNA extraction}

For the 60 LCRT subject samples, RNA was extracted from BEC samples at ResearchDx using the RNeasy Kit (Qiagen, Valencia, CA). RNA was treated with DNAse to remove gDNA contamination and assessed for RNA integrity (see below). The RNA was split into two aliquots and frozen at -80 degrees $\mathrm{C}$. One of the BEC RNA aliquots from each subject was shipped to the University of Toledo where it was first re-tested for gDNA contamination through PCR. Any samples with signal for gDNA were re-treated with DNAse. Samples then were reverse transcribed into cDNA with M-MLV reverse transcriptase (Invitrogen, Carlsbad, CA) using oligo dT primer according to the manufacturer's protocol. Genomic DNA was extracted from $\mathrm{PBC}$ at each clinical site [91], frozen and shipped to the NCI-EDRN bio-specimen bank at NCI-Frederick. One vial of DNA from each subject was provided to this lab for this study. For non-LCRT subject archival samples (120 BEC samples and 117 PBC samples), both BEC RNA and PBC DNA were extracted in this laboratory according to previously described methods [93].

\section{RNA integrity analysis}

RNA extracted from each BEC sample used in this study was assessed for RNA integrity and quantity as previously described [91]. In addition, after careful review of available RNA integrity measurement methods, we chose the $5^{\prime} / 3^{\prime}$ ratio mRNA integrity assay to assess NBEC sample RNA integrity, based on a recent comparison with other methods, including quantitative microfluidic electrophoresis [94]. This method was particularly informative because, since RNA samples were reverse transcribed with poly dT, low quality, fragmented, short length RNA would be associated with lower transcript abundance measured in assays located further away from the 3 ' end.

\section{Competitive multiplex PCR amplicon library preparation}

Targeted competitive multiplex PCR amplicon libraries were prepared to quantify total and allele-specific expression at 68 target assays on 35 genes by next generation sequencing (NGS) (in Additional file 1: Table S1) according to previously described methods [24, 26]. Genes with high prior likelihood for association with COPD-risk were selected for analysis based on careful literature review, as described in the background section. Included among these was a set of genes previously reported to be relatively unaffected by environmental variation based on cigarette smoking history [30, 40]. Primers. We designed a pool of forward and reverse primer sets targeting 68 assays in the 35 genes, using methods described in detail previously [24, 26]. When possible, we measured transcript abundance at multiple sites for each gene because it is not uncommon that probes assessing different alternative transcripts yield different expression patterns due to inter-individual biological variation $[28,95]$. For classifier gene DAE analysis, assays were selected from all exonic SNPs with minor allele frequency of $>0.05$ identified based on data from the 1000 Genomes Project [96]. Additional primer design methods are provided in Additional file 2.

\section{Internal standards (IS) and internal standard mixture}

Methods for preparation of each internal standard and the internal standard mixture were described previously [24, 26]. Details for this study are provided in Additional file 2. Preparation of a PCR amplicon library for each sample involved four sequential PCR reactions, described in 
Additional file 2. All primer and IS sequences are provided in Additional file 1: Table S1.

\section{Sequencing}

PCR library products were analyzed on an Illumina HiSeq 2500 with TruSeq SBS Kit v4 reagent at Macrogen (Macrogen, Inc., Seoul, South Korea). Macrogen then returned raw sequencing data in FASTQ format. Data Processing, calculation of total or allele-specific target transcript abundance, and filtering to avoid stochastic sampling error were described in detail in $[24,26]$. Details for this study are provided in Additional file 2.

\section{Interaction network differences between COPD cases and control}

Bivariate interactions among genes in control or COPD subjects were assessed by Pearson's correlation. Gene pair network connections were assessed for difference between COPD and control cohorts by Wilcoxon rank sum test for in- and out-degree, betweenness, and closeness, using igraph analysis as described in Additional file 2.

\section{Test for cis-rSNP enrichment among classifier genes} Inter-individual variation in DAE of a gene is a manifestation of one or more cis-rSNPs [15, 17, 19, 22, 23]. To test the question of whether cis-rSNPs are enriched in genes with COPD-associated gene expression pattern, we assessed significant difference in prevalence of DAE among COPD-associated genes compared with prevalence of DAE among all genes in multiple different tissues in prior studies $[15,17,97]$.

\section{Lung health study (LHS) and COPDgene non-Hispanic white (NHW) GWAS analysis}

Detailed methods for analysis of the LHS dataset (phs000335) and COPDgene dataset phs000765 (NHW) $[98,99]$ are provided in the Additional file 2.

\section{Sub-phenotyping of LHS and COPDgene NHW subjects}

As presented in Additional file 2: Figure S1 for LHS, prior to analysis the LHS and COPDgene NHW subjects were stratified into Chronic Bronchitis (CB) or Emphysema (EM) sub-phenotypes based on clinical annotation parameters pertaining to chronic productive cough. For LHS, following quality-control analysis a total of 3230 subjects were included. Of these, 527 were chronic bronchitis, 1198 were emphysema, and 1505 were controls. For COPDgene NHW there were a total of 5269 subjects, of which 556 were chronic bronchitis, 2223 were emphysema, and 2490 were controls.

\section{Statistical analysis}

All statistical analyses were performed using R (v 3.2.5) (http://www.R-project.org).
Shrinkage linear discriminant analysis (SLDA) to develop COPD classifier

BEC transcript abundance values for each assay in each subject were used in development of the COPD classifier model. After filtering, 32 target assays in 23 genes yielded BEC transcript abundance data for reliable total transcript abundance quantification in at least $70 \%$ of subjects and were included in statistical analyses. Typically, the cause of low subject representation for an assay was insufficient target molecules loaded into library preparation due to low BEC expression. Missing values were imputed using the corresponding mean value for each assay. Shrinkage Linear Discriminant Analysis (SLDA) was performed to select assays. The overall ranking of each assay was determined by correlationadjusted t-score (CAT scores) [100]. The 10-fold crossvalidation $(\mathrm{CV})$ receiver operating characteristic (ROC) area under the curve (AUC) was applied to identify the best sets of assays, and the pooled 10-fold crossvalidated ROC AUC was reported for the selected classifier. For each patient, the classifier assigned a probability score for COPD phenotype. An optimal cut-point to predict the class label based on Youden Index (J) was determined by repeated cross-validation step. Each patient was classified according to optimal cut-point. We compared the model predicted class label to the "true" state of COPD or control subject then calculated the diagnostic odds ratio and confidence interval.

\section{Inter-individual variation in allele-specific transcript abundance}

For each gene, and at each measured transcribed polymorphic locus, we used the F-test to compare interindividual variation in allelic imbalance in cDNA samples with that in peripheral blood genomic DNA samples. Specifically, gDNA was used as a control because it is expected that every cell will have two copies of gDNA. Therefore, under ordinary circumstances in nonmalignant cells, it is expected that the measured ratio between alleles will be close to one, subject to analytical variation. In contrast, inter-individual variation in cisregulation due to polymorphisms may cause interindividual variation in transcription of one allele to the other. Each allele ratio of read counts was log base 2 transformed prior to further analysis. F-test was performed using R (v 3.2.5) (http://www.R-project.org). GraphPad Prism was used to plot figures.

\section{Test for cis-rSNP enrichment in COPD classifier genes}

We measured DAE as an indicator that a gene contained one or more cis-rSNPs. To assess for cis-rSNP enrichment among classifier genes, we compared the fraction of genes with DAE among the genes comprised by the classifier to the fraction of genes with DAE in a large 
prior study $[15,101]$ using the $\mathrm{N}-1$ Chi-Squared test [102] at MEDCALC (https://www.medcalc.org/calc/ comparison_of_proportions.php).

\section{Bivariate analysis}

We assessed difference in inter-gene correlation of logtransformed transcript abundance by Pearson correlation coefficient ( $r$-value). We used the Fisher r-to-z transformation (Z-score) to assess the significance of difference between two correlation coefficients in two groups.

\section{Covariate analysis}

Analysis of covariance (ANCOVA) was used to assess COPD vs control group difference in transcript abundance after controlling for single covariates.

\section{Correction for multiple testing}

We used Bonferroni adjustment to correct for multiple testing in GWAS analysis. GTEx data regarding eQTL in lung tissue are reported with the $p$-values corrected for multiple testing and calculated by GTEx. We report analyses of individual gene-pair correlation changes between control and COPD and analyses of differences in means after correction for covariates (ANCOVA) without correction for multiple testing. This is justified because each of the features tested was selected for analysis based on prior association with COPD, thereby reducing likelihood of false discovery.

\section{Results}

\section{RNA and DNA samples}

RNA extracted from each BEC sample met previously described thresholds for RNA integrity and quantity as described in methods [91].

\section{Targeted RNAseq expression data}

Total transcript abundance values meeting the QC threshold were obtained in BEC samples from at least $70 \%$ of subjects for 32 target assays in 23 genes and this set was used in univariate and multivariate analyses.

\section{Interaction network differences between COPD cases and control}

On a network basis, TP53 and CEBP transcription factor pathway gene pair network connections were different between COPD and control cohorts as measured by Wilcoxon rank sum test for in- and out-degree ( $p$-value $=$ $7.0 \mathrm{E}-05)$, betweenness $(p$-value $=0.00437)$, and closeness $(p$-value $=5.0 \mathrm{E}-11)($ Fig. 2$)$. Consistent with this, the total number of inter-gene correlation connections (lines) among the tested assays was higher among COPD individuals. Inter-gene correlation data in relationship to transcription factors are presented in Additional file 1: Table S3. Notably, ERCC5 was more highly correlated with both
CEBPD and TP73 in COPD compared with controls (Fig. 3, Additional file 1: Table S3). In contrast, CEPBD correlation with TP53 was decreased in COPD.

\section{Analysis of covariance (ANCOVA)}

After adjustment for covariate effects, there was a difference in mean expression between COPD and controls for several classifier genes. Specifically CEBPG, GPX1, and TP73 were expressed at a higher level in COPD compared to controls while KEAP1 was expressed at a lower level (Additional file 1: Table S4).

\section{Identification of genes with COPD-associated expression pattern}

SLDA was used to rank each feature for classification ability according to correlation-adjusted $\mathrm{t}$ (CAT)-score (See Additional file 1: Table S1). After 10-fold crossvalidation, the classifier with best ROC AUC comprised nine features, including the three demographic variables sex, age, and smoking history in pack-years, and six genes: CAT, CEBPG, GPX1, KEAP1, TP73, and XPA (Fig. 4, Table 2, and Additional file 1: Table S1 rows 1419). The 10-fold cross-validation AUC for the model was $75.4 \%$ (95\% CI: 66.3\%-89.3\%). As reported above, ERCC5 has altered correlation with transcription factor TP73 comprised by the classifier (Fig. 3) and other genes as measured by iGraph (Fig. 2).

\section{Query of LHS GWAS for targeted genes}

Details of LHS GWAS analysis are provided in Additional file 2: Figure S1). Briefly, the LHS COPD GWAS subjects were stratified into chronic bronchitis (CB) or emphysema (EM) sub-phenotypes. All LHS SNPs that passed quality control were restricted to putative cisregulatory regions. Then, SNPs in this restricted set with $p<0.05$ for association with LHS CB or LHS EM subjects were identified. The resulting SNP sets were designated \{LHS CB Restricted\} and \{LHS EM Restricted\}.

\section{Integration of restricted LHS SNP sets with genes targeted in this study}

The intersection of the 35 genes targeted in this study with the \{LHS CB Restricted\} SNP set comprised six linked SNPs in ERCC5, each with $P<0.05$ (Additional file 1: Table S5). In contrast, no SNPs were identified in the intersection of the 35 targeted genes and the \{LHS EM Restricted\} SNP set.

\section{Validation of ERCC5 SNP association with chronic bronchitis in the COPDgene cohort}

The independent COPDgene NHW phs000765 cohort [3, 98] was stratified according to CB or EM sub-phenotype using the same criteria used to sub-phenotype LHS. COPDgene NHW CB and COPDgene NHW EM were each 


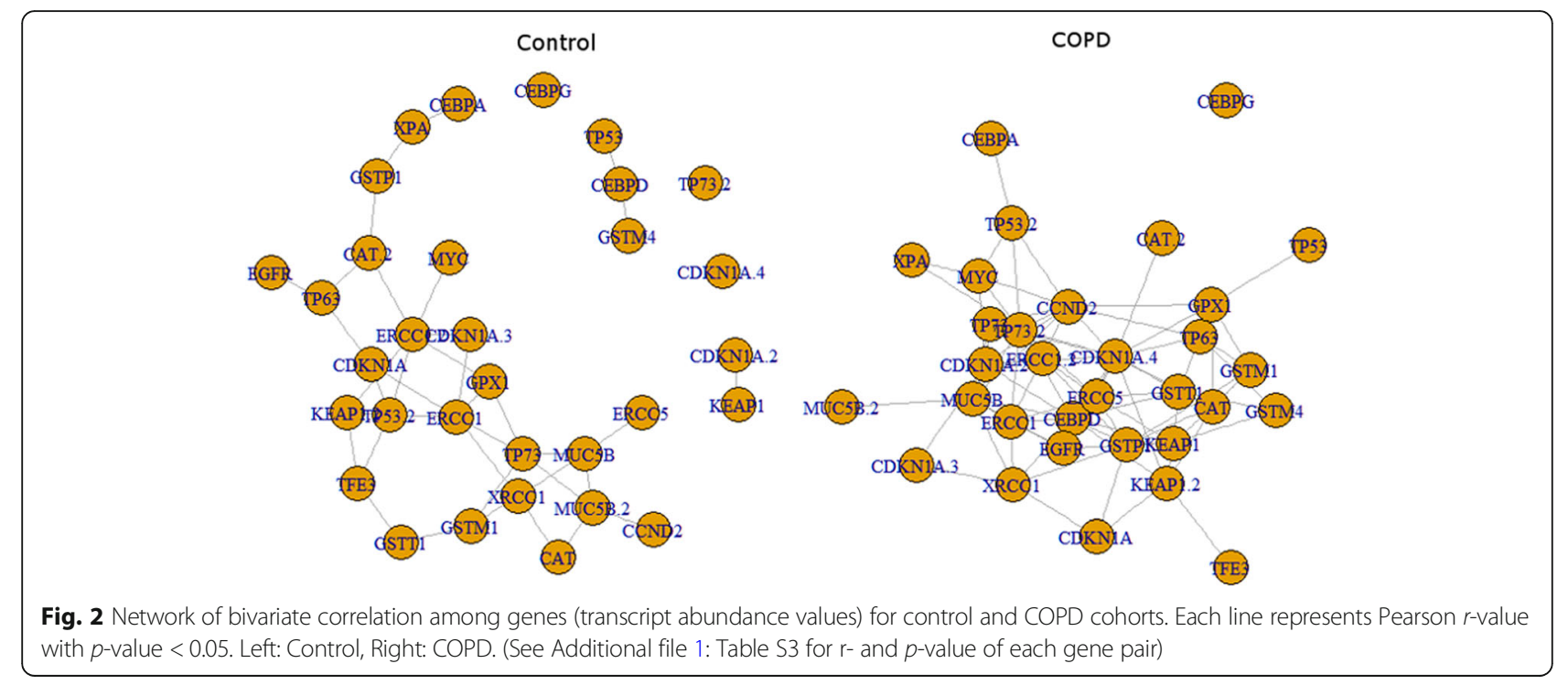

queried for rs4150275, which was chosen to represent the 6 linked SNPs (Additional file 2: Figure S2). In this validation test, because one SNP was queried in two sub-phenotypes, the Bonferonni adjusted threshold for significance was $\mathrm{a}=$ $0.05 / 2=0.025$. As with LHS analysis, rs4150275 was significant in COPDgene NHW CB $(p=0.0046)$ but not COPDgene NHW EM. Importantly, the haplotype represented by rs4150275 allele A was associated with CB in both LHS and COPDgene NHW.

\section{Assessment of genes with COPD-associated RNAseq pat- terns for DAE in BEC}

ERCC5 displays inter-individual variation in DAE in BEC, measured at multiple SNPs, including rs17655, which is linked (D') to rs4150275) [93]. Further, rs873601 which is linked to rs17655 is predicted to alter miRNA binding sites and likely plays a key functional cis-regulatory role [103].

We identified at least one expressed SNP with MAF > 0.05 in four of the six COPD classifier genes selected by
SLDA; CAT: rs1049982, CEBPG: rs3745968, KEAP1:rs1048287, and TP73:rs1801174. For each of these SNPs, the number of heterozygotes among the cDNA samples was close to Hardy-Weinberg Equilibrium expectations (Table 3) and comparable to that observed among gDNA samples. Inter-individual variation in allelic-imbalance in cDNA was significantly higher $(\mathrm{p}<0.05)$ than that in gDNA at each of these four sites after Bonferroni adjustment for multiple testing (Table 3, Fig. 5). The rate of DAE among ERCC5 and the four measurable classifier genes was $100 \%$ $(4 / 4)$ which was significantly higher $(p=0.0023)$ than the $30 \%$ of genes that demonstrated DAE in lung tissue (5884/ 19,725) [17] or lymphoblastoid cell lines (2935/9751) [101].

\section{Assessment of BEC putative cis-rSNPs for lung tissue} quantitative trait loci (eQTL) status in GTEx database We queried the Genotype-Tissue Expression (GTEx) database $[17,104]$ for lung tissue eQTL at SNPs in that were associated with $\mathrm{DAE}$ in $\mathrm{BEC}$, including classifier
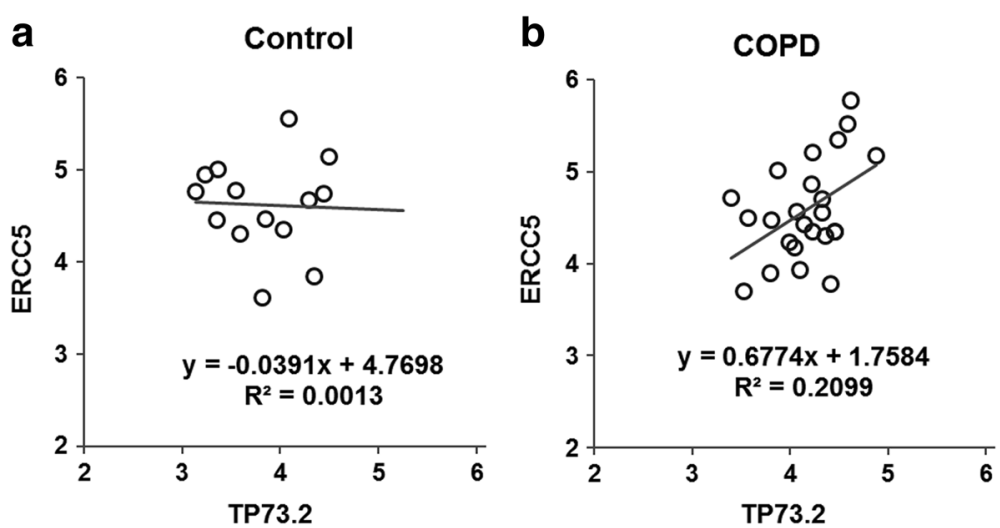

Fig. 3 Inter-gene correlation differences in control vs COPD cohorts. a, b TP73-2 vs ERCC5 


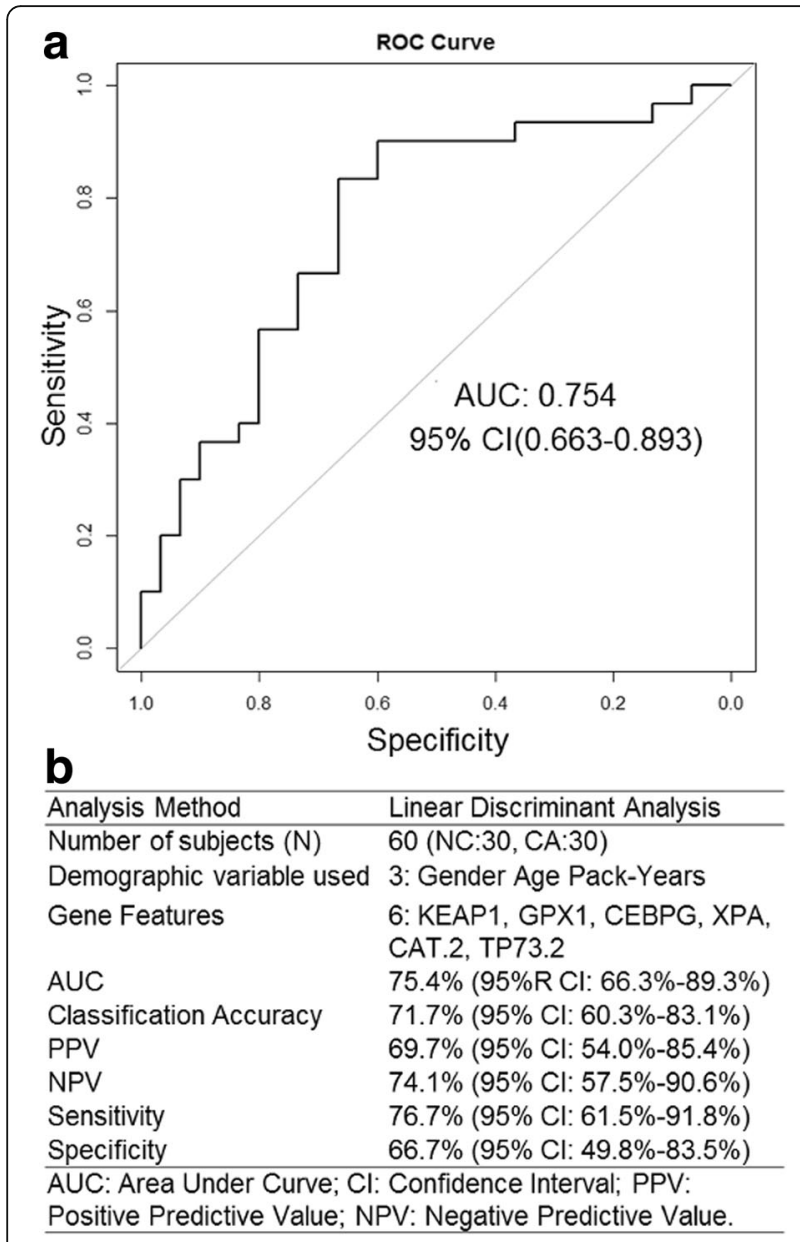

Fig. 4 Receiver operating characteristic curve (ROC) (a) and summary of performance of classifier (b) in 30 control and 30 COPD subjects

genes CAT, CEBPG, GPX1, and TP73 (Table 3), and ERCC5. GTEx measured eQTL as dose-effect of genotype on total transcript abundance. SNPs associated with lung tissue eQTL include rs17655 ( $p=3.2 \mathrm{E}-7)$, located in the 3' untranslated region of ERCC5, and rs1049982 ( $p=1.95 \mathrm{E}-08)$, located in the promoter of CAT. Notably, for each of these SNPs, the same allele associated with

Table 2 COPD classifier gene features selected by SLDA ${ }^{1}$ and 10-fold cross-validation

\begin{tabular}{lllll}
\hline Feature & Gene Function & CAT $^{2}$ score & Ranking & Missing value (\%) \\
\hline KEAP1 & $\mathrm{AO}^{3}$ & 3.35 & 1 & $8 \%$ \\
GPX1 & $\mathrm{AO}$ & 3.32 & 2 & $5 \%$ \\
CEBPG & $\mathrm{TF}^{4}$ & 2.98 & 3 & $18 \%$ \\
XPA & DNAR $^{5}$ & 2.64 & 4 & $28 \%$ \\
CAT-2 & $\mathrm{AO}$ & 2.64 & 5 & $22 \%$ \\
TP73-2 & $\mathrm{CCC}^{6} / \mathrm{DNAR}$ & 2.30 & 6 & $28 \%$ \\
\hline
\end{tabular}

${ }^{1} S L D A$ shrinkage linear discriminant analysis, ${ }^{2} C A T$ score correlation-adjusted tscores, ${ }^{3} \mathrm{AO}$ antioxidant, ${ }^{4} \mathrm{TF}$ transcription factor, ${ }^{5} \mathrm{DNAR}$ DNA repair, ${ }^{6} \mathrm{CCC}$ cell cycle control higher expression in GTEx lung tissue was significantly more likely to be expressed at higher level than the opposite allele in BEC. SNPs associated with BEC DAE in the other genes were not associated with significant eQTL in lung tissue in GTEx (Table 3).

\section{Discussion}

Data reported here support the hypothesis that loweffect COPD risk/pathogenesis SNPs may be discovered through enrichment as cis-regulatory SNPs in genes that display COPD-associated BEC expression patterns. Moreover, by integrating the BEC RNAseq data with COPD GWAS [98, 99], ENCODE [105], and GTEx [17, 104] databases, we identified ERCC5 SNP rs 873601 as a plausible functional connection between ERCC5 DAE (measured at rs17655), and association of rs4150275 with chronic bronchitis in COPD GWAS (Additional file 1: Table S6). [103, 106]. Thus, these data support the role of rs873601 in ERCC5 cis-regulation associated with COPD pathogenesis and risk. That said, other SNPs linked to rs4150275 also are predicted to affect binding of transacting proteins and also could play a role (Additional file 1: Table S5).

\section{Putative cis-regulatory SNPs in SLDA classifier genes}

CAT SNP rs1049982 is predicted to have cis-regulatory function because it is in the $5^{\prime}$ untranslated region near the promoter and affects binding of POLR2A. In addition, this SNP was identified as a lung tissue eQTL in lung tissue $[17,104]$. Based on these characteristics, this SNP would be a suitable target for experimental confirmation of function in BEC [107]. With respect to CEBPG, KEAP1, and TP73 it is likely that SNPs other than those used to measure DAE in this study are responsible for cis-regulation of these genes in BEC and additional experimental studies will be necessary to answer this question.

COPD-associated SNPs have been reported for several of the classifier genes (see background section) but, to our knowledge, not validated in individual GWAS. It will be worthwhile to assess recently completed COPD meta-analysis GWAS for SNPs in these genes using reduced stringency for false reporting.

\section{Effect of study design characteristics selected to optimize power}

Several methodological approaches were implemented in this study to maximize the power to identify BEC transcription patterns associated with COPD. For example, genes with high prior likelihood for hereditary COPDrisk association were targeted. In addition, a transcript abundance measurement platform with excellent analytical performance characteristics was used. Specifically, there was no measurable signal-to-analyte compression 
Table 3 SLDA COPD classifier gene differential allelic expression (DAE) in bronchial epithelial cell (BEC) or in GTEx lung tissue database

\begin{tabular}{|c|c|c|c|c|c|c|}
\hline & & \multicolumn{3}{|l|}{ DAE in BEC } & \multicolumn{2}{|c|}{ GTEx Lung Tissue $(n=278)$} \\
\hline${ }^{1} \mathrm{SNP}$ & MAF & Subjects Assessed (n) & ${ }^{2}$ Heterozygote Subjects with DAE data $(n)$ & ${ }^{3} p$-value & 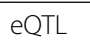 & ${ }^{4} p$-value \\
\hline KEAP1-rs1048287 & 0.1 & 159 & 30 & $9.02 E-10$ & KEAP1 & ${ }^{5} \mathrm{~N} \cdot \mathrm{R}$. \\
\hline CEBPG-rs3745968 & 0.11 & 128 & 17 & $6.35 E-04$ & CEBPG & N.R. \\
\hline CAT-rs1049982 & 0.34 & 156 & 52 & $1.51 E-24$ & CAT & $1.95 E-08$ \\
\hline TP73-rs1801174 & 0.09 & 158 & 27 & $1.34 E-10$ & TP73 & N.R. \\
\hline
\end{tabular}

Significant $p$-values indicated in italicized font

${ }^{1}$ SNP that served as marker for DAE. SNPs with highest minor allele frequency chosen

${ }^{2} n=$ number of subjects for whom each SNP allele was measurable in BEC after filtering to prevent stochastic sampling error. The fraction of gDNA samples with heterozygotes was comparable to that for cDNA samples and both approximated Hardy Weinberg Equilibrium expectations

${ }^{3} p$-value for F-test comparing inter-individual variation in cDNA to inter-individual variation in gDNA samples

${ }^{4} \mathrm{p}$-value reported in GTEx database

${ }^{5} N \cdot R$ not reported

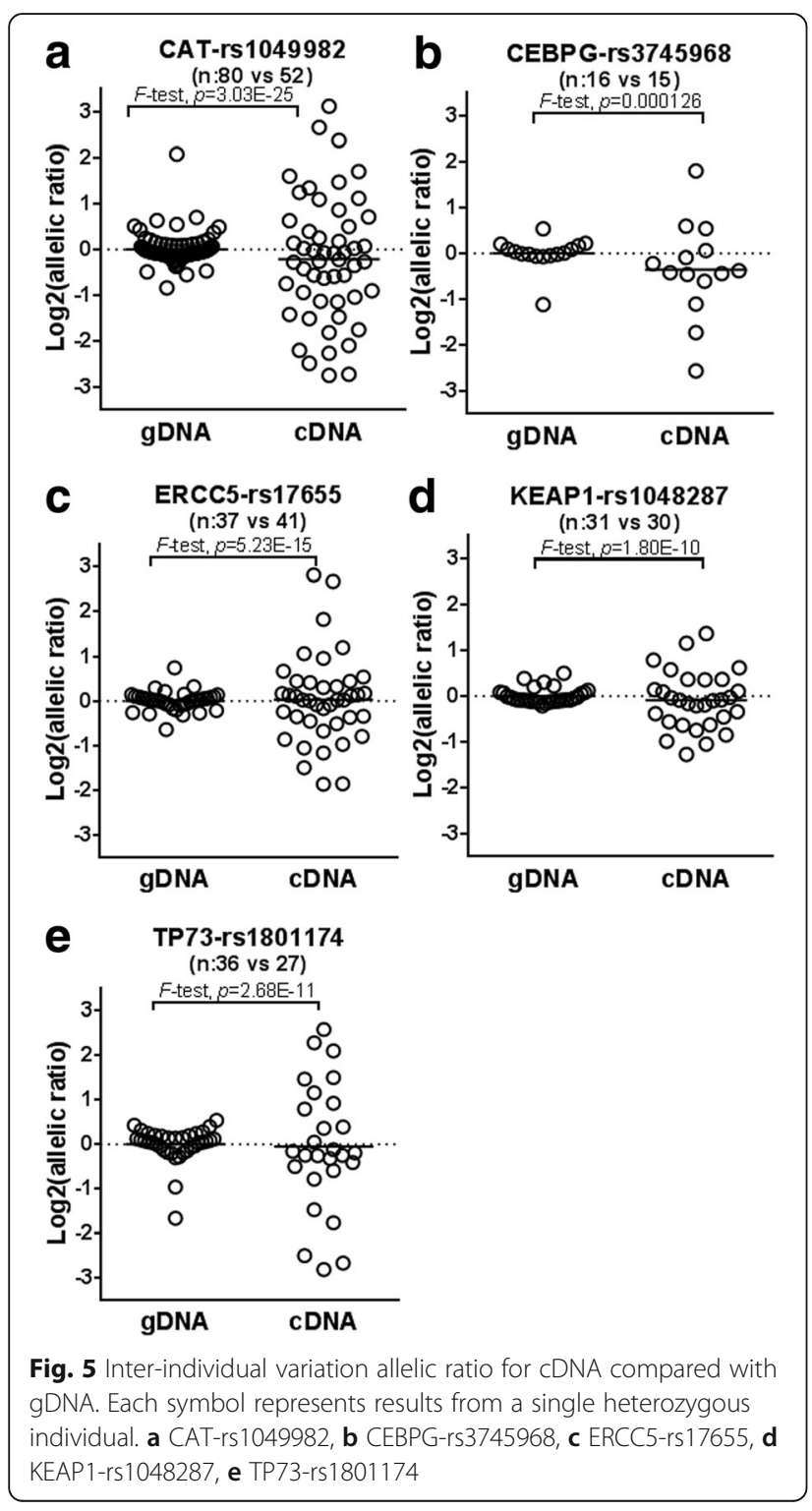

with the method used in this study $[25,28]$ and the targeted PCR method used resulted in abundant signal for each analyte. This resulted in robust collection of data from each specimen, comparing favorably with other methods, such as microarrays or whole exome sequencing analysis [8, 17, 41]. Moreover, analysis of cell populations homogeneous for a particular cell type, such as the homogeneous BEC population samples in this study, increases the power to identify disease-associated transcript abundance patterns and eQTL [95, 108, 109]. According to ASE measurement by targeted RNAseq, DAE was clearly detected for marker SNPs in classifier genes CEBPG, KEAP1, and TP73 in BEC (Table 3). However, lung tissue eQTL was not reported for any SNPs in these genes measured by whole transcriptome RNAseq in GTEx study [17]. This observation is likely due to difference in specimen type (i.e. homogeneous BEC vs heterogeneous lung tissue), and deeper coverage obtained by targeted RNAseq for ASE in this study.

\section{Limits of study and opportunities}

It is evident that COPD risk SNPs discovered in the future will have low effect because they are very rare and/ or they are common but their individual contribution to risk is low. Results presented here exemplify both the challenge to identify low-effect complex disease risk variants and the opportunity of the approach used. The low effect of rs4150275 is likely due to multiple factors. For example, the rs4150275 A allele prevalence in European populations is $5 \%$. Moreover, rs873601, the putative functional SNP linked to DAE SNP rs17655 and COPD risk SNP rs4150275, may be one of multiple SNPs that contribute to ERCC5 transcription regulation [93]. As such, there is a need to directly measure function of putative cis-regulatory SNPs through recently developed high throughput NGS methods [110-112]. Another factor contributing to low effect of rs4150275 is that, based on data presented here, ERCC5 is likely one of many 
genes that contribute to COPD risk when sub-optimally regulated. In this study we increased the power to identify COPD risk SNPs with cis-regulatory function in BEC by studying homogeneous BEC biospecimens. It is likely that hereditary variants affecting gene expression in lung fibroblasts and immune cells also contribute to COPD predisposition. Thus, homogeneous populations of these cell types should be included in future studies.

\section{Conclusion}

We report that low-effect COPD risk SNPs may be identified through enrichment as cis-regulatory SNPs in genes that display COPD-associated BEC expression patterns. These findings support broader application of the approach presented here, including further targeted RNAseq analysis of BEC and homogeneous populations of other lung cell types to identify COPD associated expression patterns and cis-rSNPs in genes comprised by the expression patterns, followed by test of associated cis-rSNPs in large GWAS meta-analyses. This approach promises to facilitate progress toward the important goal of identifying a set of COPD risk variants with sufficient effect on COPD pathogenesis and variation in hereditary risk to have clinical utility. This knowledge is expected to lead to better COPD prevention and treatment strategies.

\section{Additional files}

Additional file 1: Tables S1, S2, S3, S4, S5 and S6. Table S1. This table provides: a) Gene-specific assay information including SNP sites, primer and internal standard sequences, b) Subject-specific demographic information, and c) assay- and subject-specific transcript abundance values (target gene molecules $/ 10^{6}$ ACTB molecules). Table S2. Population used for allele specific expression analysis: Summary demographic characteristics of the study population of allele specific expression (subject total $n=180$ ). Table S3. Transcription factor-target inter-gene correlation in Control, COPD, or All subjects ( $p$-value $<0.05$ ). Table S4. Analysis of covariance (ANCOVA). Gene expression values (Independent Variables) significantly correlated (positively or negatively) with COPD subjects (Dependent Variable) after control for expression values of other genes (Covariates). Table S5. ERCC5 SNPs linked to rs 17655 and rs873601 (D > 0.95) and with $p<0.05$ in LHS and COPDgene NHW CB cohorts. COPD GWAS p-values, population-specific genotype frequencies, and epigenetic annotation information from Haploreg/Encode. Table S6. Haplotype structure between COPDgene NHW' associated SNP rs4150275, putative functional cis-rSNP rs873601, and DAE ${ }^{2}$ SNP rs 17655. (XLSX $109 \mathrm{~kb})$

Additional file 2: Supplementary Methods, and Figures S1 and S2. Supplementary Methods: Study subjects and tissues, RNA and DNA extraction, preparation of internal standard mixture (ISM) primers, PCR steps, sequencing, data processing and calculation of total or allelespecific target transcript abundance, filtering against stochastic sampling error, Measurement of inter-individual variation in allele-specific transcript abundance, Assessment of BEC eQTL in publically available GenotypeTissue Expression (GTEx) database, GWAS analysis, sub-phenotyping of LHS and COPDgene NHW subjects, restriction of LHS GWAS SNP set, and integration of COPD-associated putative cis-rSNPs with GWAS. Figure S1. LHS Sub-phenotyping and SNP Restriction. Figure S2. Integration of 35 targeted genes with \{LHS CB Restricted $\}$ and \{LHS EM Restricted\} SNP sets, followed by test for validation in the COPDgene NHW CB and EM COhorts. (DOCX $93 \mathrm{~kb}$ )

\section{Abbreviations}

ANCOVA: Analysis of covariance; ASE: Allele specific expression; AUC: Area under the curve; BEC: Bronchial epithelial cell; CAT: Correlation adjusted t; CB: Chronic bronchitis; cis-rSNP: cis-regulatory single nucleotide polymorphism; COPD: Chronic obstructive pulmonary disease; DAE: Differential allelic expression; EM: Emphysema; eQTL: Expression quantitative trait loci; GM: Genome maintenance; GTEX: Genotype-Tissue Expression; GWAS: Genome-wide association studies; IRB: Institutional Review Board; IS: Internal standard; LCRT: Lung cancer risk test; LHS: Lung health study; NGS: Next generation sequencing; NHW: Non-Hispanic white; ROC: Receiver Operator Characteristic; SLDA: Shrinkage linear discriminant analysis; SNP: Single nucleotide polymorphism

\section{Acknowledgements}

Inchul Yang (Korean Research Institute for Standards Science: KRISS) for many insightful comments; Fluidigm Corporation (South San Francisco, CA) for generous loan and support of Access Array ${ }^{\mathrm{TM}}$ instrument.

\section{Funding}

$\mathrm{NIH}$ grants CA148572 and HL108016; The George Isaac Cancer Research Fund; Fluidigm Corporation (South San Francisco, CA), loan and support of Access Array ${ }^{\mathrm{TM}}$ instrument.

\section{Availability of data and materials}

The majority of the data generated for this study are available in the additional files. The complete datasets analyzed during this study are available from the corresponding author upon reasonable request.

\section{Authors' contributions}

JY: experimental design, RNAseq experiments, data analysis, manuscript preparation; DAM, SQ, AF: GWAS analysis; TC, SAK: SLDA modeling, manuscript preparation; ELC: RNAseq experiments; XZ: RNAseq experiments, GTEx analysis; TMB: RNAseq data analysis, manuscript preparation; AML: GWAS analysis, manuscript preparation; PPM, DAA, DEM, PJM, SDN, RJW, PNS, $\mathrm{DRH}, J \mathrm{RH}, \mathrm{YY}$, and FS: subject enrollment, biospecimen collection, manuscript preparation; PFSW, KP, TJA: PBL DNA extraction, Haploreg analysis; JCW: experimental design, data analysis, biospecimen collection, LCRT trial site coordination, manuscript preparation. All authors read and approved the final manuscript.

\section{Ethics approval and consent to participate}

Collection and use of samples and corresponding medical/demographic data was approved under University of Toledo IRB protocols \#108538 and \#107844. Each subject included in this study provided written informed consent.

\section{Consent for publication}

Not applicable.

\section{Competing interests}

JCW is a consultant for and has equity interest in Accugenomics, Inc. which has a financial interest in the data presented here. JCW, TB and ELC have issued and pending patents for the technology and biomarkers presented here. Other authors declare that they have no competing interests.

\section{Publisher's Note}

Springer Nature remains neutral with regard to jurisdictional claims in published maps and institutional affiliations.

\section{Author details}

'Department of Pathology, The University of Toledo College of Medicine, 3000 Arlington Avenue, HEB 219, Toledo, OH 43614, USA. ${ }^{2}$ Division of Pulmonary and Critical Care Medicine, Department of Medicine, The University of Toledo College of Medicine, 3000 Arlington Avenue, HEB 219, Toledo, OH 43614, USA. ${ }^{3}$ Department of Mathematics and Statistics, The University of Toledo, 2801 W. Bancroft Street, Toledo, OH 43606, USA. ${ }^{4}$ Department of Medicine, The University of Toledo College of Medicine, 3000 Arlington Avenue, Toledo, OH 43614, USA. ${ }^{5}$ Department of Biostatistics, Henry Ford Health System, 1 Ford Place Detroit, MI, Detroit, MI 48202, USA. ${ }^{6}$ Thoracic Program, Vanderbilt Ingram Cancer Center, Nashville, TN 37232, USA. ${ }^{7}$ University of Michigan, 500 S. State Street, Ann Arbor, Ml 48109, USA. 
${ }^{8}$ Department of Pulmonary and Critical Care Medicine, Mayo Clinic, 200 1st St SW, Rochester, MN 55905, USA. ${ }^{9}$ Department of Pulmonary Medicine, Cleveland Clinic, 9500 Euclid Ave, Cleveland, OH 44195, USA. ${ }^{10}$ Department of Pulmonary Medicine, Inova Fairfax Hospital, 3300 Gallows Road, Falls Church, VA 22042-3300, USA. ${ }^{11}$ The Toledo Hospital, 2142 N Cove Blvd, Toledo, OH 43606, USA. ${ }^{12}$ Division of Pulmonary Diseases and Critical Care Medicine, Virginia Commonwealth University, USA, Richmond, VA 23284-2512, USA. ${ }^{13}$ Ohio State University James Comprehensive Cancer Center and Solove Research Institute, Columbus, OH, USA. ${ }^{14}$ American Enterprise Institute, 1789 Massachusetts Ave NW, Washington, DC 20036, USA. ${ }^{15}$ The University of Toledo College of Medicine, 3000 Arlington Avenue, Toledo, OH 43614, USA. ${ }^{16}$ Emory University School of Medicine, 1648 Pierce Dr NE, Atlanta, GA 30307, USA. ${ }^{17}$ Department of Medicine, The University of Toledo Medical Center, 3000 Arlington Avenue, Toledo, OH 43614, USA.

${ }^{18}$ Division of Pulmonary and Critical Care Medicine, Department of Medicine, The University of Toledo College of Medicine, 3000 Arlington Avenue, RHC 0012, Toledo, $\mathrm{OH} 43614$, USA. ${ }^{19}$ Division of Pulmonary and Critical Care Medicine, Department of Medicine, The University of Toledo College of Medicine, 3000 Arlington Avenue, Toledo, OH 43614, USA.

\section{Received: 8 November 2017 Accepted: 23 February 2018} Published online: 05 March 2018

\section{References}

1. Rennard SI. COPD: overview of definitions, epidemiology, and factors influencing its development. Chest. 1998;113(4 Suppl):235S-41S.

2. Zhou JJ, Cho MH, Castaldi PJ, Hersh CP, Silverman EK, Laird NM. Heritability of chronic obstructive pulmonary disease and related phenotypes in smokers. Am J Respir Crit Care Med. 2013;188(8):941-7.

3. Cho MH, McDonald ML, Zhou X, Mattheisen M, Castaldi PJ, Hersh CP, Demeo DL, Sylvia JS, Ziniti J, Laird NM, et al. Risk loci for chronic obstructive pulmonary disease: a genome-wide association study and meta-analysis. Lancet Respir Med. 2014;2(3):214-25.

4. Todd JL, Goldstein DB, Ge D, Christie J, Palmer SM. The state of genomewide association studies in pulmonary disease: a new perspective. Am J Respir Crit Care Med. 2011;184(8):873-80.

5. Qiao D, Lange C, Beaty TH, Crapo JD, Barnes KC, Bamshad M, Hersh CP, Morrow J, Pinto-Plata VM, Marchetti N, et al. Exome sequencing analysis in severe, early-onset chronic obstructive pulmonary disease. Am J Respir Crit Care Med. 2016;193(12):1353-63.

6. Busch R, Hobbs BD, Zhou J, Castaldi PJ, McGeachie MJ, Hardin ME, Hawrylkiewicz I, Sliwinski P, Yim JJ, Kim WJ, et al. Genetic association and risk scores in a COPD meta-analysis of 16,707 subjects. Am J Respir Cell Mol Biol. 2017;57(1):35-45.

7. Wain LV, Shrine N, Artigas MS, Erzurumluoglu AM, Noyvert B, Bossini-Castillo L, Me O, Henry AP, Portelli MA, Hall RJ, et al. Genome-wide association analyses for lung function and chronic obstructive pulmonary disease identify new loci and potential druggable targets. Nat Genet. 2017;49(3):416-25.

8. Steiling K, van den Berge M, Hijazi K, Florido R, Campbell J, Liu G, Xiao J, Zhang XH, Duclos G, Drizik E, et al. A dynamic bronchial airway gene expression signature of chronic obstructive pulmonary disease and lung function impairment. Am J Respir Crit Care Med. 2013;187(9):933-42.

9. Shaykhiev R, Crystal RG. Early events in the pathogenesis of chronic obstructive pulmonary disease. Smoking-induced reprogramming of airway epithelial basal progenitor cells. Ann Am Thorac Soc. 2014;11(Suppl 5):S252-8.

10. Pierrou S, Broberg P, O'Donnell RA, Pawlowski $K$, Virtala R, Lindqvist $E$, Richter A, Wilson SJ, Angco G, Moller S, et al. Expression of genes involved in oxidative stress responses in airway epithelial cells of smokers with chronic obstructive pulmonary disease. Am J Respir Crit Care Med. 2007; 175(6):577-86.

11. Emilsson V, Thorleifsson G, Zhang B, Leonardson AS, Zink F, Zhu J, Carlson S, Helgason A, Walters GB, Gunnarsdottir S, et al. Genetics of gene expression and its effect on disease. Nature. 2008;452(7186):423-8.

12. Albert FW, Kruglyak $L$. The role of regulatory variation in complex traits and disease. Nat Rev Genet. 2015;16(4):197-212.

13. Fehrmann RS, Jansen RC, Veldink JH, Westra HJ, Arends D, Bonder MJ, Fu J, Deelen P, Groen HJ, Smolonska A, et al. Trans-eQTLs reveal that independent genetic variants associated with a complex phenotype converge on intermediate genes, with a major role for the HLA. PLoS Genet. 2011;7(8):e1002197.
14. Grundberg E, Small KS, Hedman AK, Nica AC, Buil A, Keildson S, Bell JT, Yang TP, Meduri E, Barrett A, et al. Mapping cis- and trans-regulatory effects across multiple tissues in twins. Nat Genet. 2012;44(10):1084-9.

15. Hamdi Y, Soucy P, Adoue V, Michailidou K, Canisius S, Lemacon A, Droit A, Andrulis IL, Anton-Culver $\mathrm{H}$, Arndt $\mathrm{V}$, et al. Association of breast cancer risk with genetic variants showing differential allelic expression: identification of a novel breast cancer susceptibility locus at 4q21. Oncotarget. 2016;7(49):80140-63.

16. Maurano MT, Humbert R, Rynes E, Thurman RE, Haugen E, Wang $H$, Reynolds AP, Sandstrom R, Qu H, Brody J, et al. Systematic localization of common disease-associated variation in regulatory DNA. Science. 2012; 337(6099):1190-5.

17. Battle A, Brown CD, Engelhardt BE, Montgomery SB. Genetic effects on gene expression across human tissues. Nature. 2017;550(7675):204-13.

18. Schadt EE, Molony C, Chudin E, Hao K, Yang X, Lum PY, Kasarskis A, Zhang $B$, Wang $S$, Suver $C$, et al. Mapping the genetic architecture of gene expression in human liver. PLoS Biol. 2008;6(5):e107.

19. Castaldi PJ, Cho MH, Zhou X, Qiu W, McGeachie M, Celli B, Bakke P, Gulsvik A, Lomas DA, Crapo JD, et al. Genetic control of gene expression at novel and established chronic obstructive pulmonary disease loci. Hum Mol Genet. 2015;24(4):1200-10.

20. Yan H, Yuan W, Velculescu VE, Vogelstein B, Kinzler KW. Allelic variation in human gene expression. Science. 2002;297(5584):1143.

21. Kang EY, Martin LJ, Mangul S, Isvilanonda W, Zou J, Ben-David E, Han B, Lusis AJ, Shifman S, Eskin E. Discovering single nucleotide polymorphisms regulating human gene expression using allele specific expression from RNA-seq data. Genetics. 2016;204(3):1057-64.

22. Almlof JC, Lundmark P, Lundmark A, Ge B, Maouche S, Goring HH, Liljedahl U, Enstrom C, Brocheton J, Proust C, et al. Powerful identification of cisregulatory SNPs in human primary monocytes using allele-specific gene expression. PLoS One. 2012;7(12):e52260.

23. Castel SE, Levy-Moonshine A, Mohammadi P, Banks E, Lappalainen T. Tools and best practices for data processing in allelic expression analysis. Genome Biol. 2015;16:195.

24. Blomquist TM, Crawford EL, Lovett JL, Yeo J, Stanoszek LM, Levin A, Li J, Lu M, Shi L, Muldrew K, et al. Targeted RNA-sequencing with competitive multiplex-PCR amplicon libraries. PLoS One. 2013:8(11):e79120.

25. Blomquist T, Crawford EL, Mullins D, Yoon Y, Hernandez DA, Khuder S, Ruppel PL, Peters E, Oldfield DJ, Austermiller B, et al. Pattern of antioxidant and DNA repair gene expression in normal airway epithelium associated with lung cancer diagnosis. Cancer Res. 2009;69(22):8629-35.

26. Blomquist T, Crawford EL, Yeo J, Zhang X, Willey JC. Control for stochastic sampling variation and qualitative sequencing error in next generation sequencing. Biomol Detect Quantif. 2015;5:30-7.

27. Blomquist TM, Crawford EL, Willey JC. Cis-acting genetic variation at an E2F1/YY1 response site and putative p53 site is associated with altered allele-specific expression of ERCC5 (XPG) transcript in normal human bronchial epithelium. Carcinogenesis. 2010;31(7):1242-50.

28. Canales RD, Luo Y, Willey JC, Austermiller B, Barbacioru CC, Boysen C, Hunkapiller K, Jensen RV, Knight CR, Lee KY, et al. Evaluation of DNA microarray results with quantitative gene expression platforms. Nat Biotechnol. 2006;24(9):1115-22.

29. Crawford EL, Blomquist T, Mullins DN, Yoon Y, Hernandez DR, Al-Bagdhadi M, Ruiz J, Hammersley J, Willey JC. CEBPG regulates ERCC5/XPG expression in human bronchial epithelial cells and this regulation is modified by E2F1/ YY1 interactions. Carcinogenesis. 2007;28(12):2552-9.

30. Mullins DN, Crawford EL, Khuder SA, Hernandez DA, Yoon Y, Willey JC. CEBPG transcription factor correlates with antioxidant and DNA repair genes in normal bronchial epithelial cells but not in individuals with bronchogenic carcinoma. BMC Cancer. 2005:5:141.

31. Yeo J, Crawford EL, Blomquist TM, Stanoszek LM, Dannemiller RE, Zyrek J, De Las Casas LE, Khuder SA, Willey JC. A multiplex two-color real-time PCR method for quality-controlled molecular diagnostic testing of FFPE samples. PLoS One. 2014;9(2):e89395.

32. Crawford EL, Warner KA, Khuder SA, Zahorchak RJ, Willey JC. Multiplex standardized RT-PCR for expression analysis of many genes in small samples. Biochem Biophys Res Commun. 2002;293(1):509-16.

33. Crawford EL, Peters GJ, Noordhuis P, Rots MG, Vondracek M, Grafstrom RC, Lieuallen K, Lennon G, Zahorchak RJ, Georgeson MJ, et al. Reproducible gene expression measurement among multiple laboratories obtained in a blinded study using standardized RT (StaRT)-PCR. Mol Diagn. 2001;6(4): 217-25. 
34. Cheung VG, Spielman RS, Ewens KG, Weber TM, Morley M, Burdick JT. Mapping determinants of human gene expression by regional and genome-wide association. Nature. 2005;437(7063):1365-9.

35. Schadt EE, Monks SA, Drake TA, Lusis AJ, Che N, Colinayo V, Ruff TG, Milligan $\mathrm{SB}$, Lamb JR, Cavet G, et al. Genetics of gene expression surveyed in maize, mouse and man. Nature. 2003:422(6929):297-302.

36. Stranger BE, Forrest MS, Clark AG, Minichiello MJ, Deutsch S, Lyle R, Hunt S, Kahl B, Antonarakis SE, Tavare $\mathrm{S}$, et al. Genome-wide associations of gene expression variation in humans. PLoS Genet. 2005;1(6):e78.

37. Skelly DA, Johansson M, Madeoy J, Wakefield J, Akey JM. A powerful and flexible statistical framework for testing hypotheses of allele-specific gene expression from RNA-seq data. Genome Res. 2011;21(10):1728-37.

38. Blomquist TM, Brown RD, Crawford EL, de la Serna I, Williams K, Yoon Y, Hernandez DA, Willey JC. CEBPG exhibits allele-specific expression in human bronchial epithelial cells. Gene regul syst biol. 2013;7:125-38.

39. Brumpton BM, Ferreira MA. Multivariate eQTL mapping uncovers functional variation on the X-chromosome associated with complex disease traits. Hum Genet. 2016;135(7):827-39.

40. Crawford EL, Khuder SA, Durham SJ, Frampton M, Utell M, Thilly WG Weaver DA, Ferencak WJ, Jennings CA, Hammersley JR, et al. Normal bronchial epithelial cell expression of glutathione transferase P1, glutathione transferase M3, and glutathione peroxidase is low in subjects with bronchogenic carcinoma. Cancer Res. 2000;60(6):1609-18.

41. Tilley AE, O'Connor TP, Hackett NR, Strulovici-Barel Y, Salit J, Amoroso N, Zhou XK, Raman T, Omberg L, Clark A, et al. Biologic phenotyping of the human small airway epithelial response to cigarette smoking. PLoS One. 2011;6(7):e22798.

42. Barnes PJ. Cellular and molecular mechanisms of chronic obstructive pulmonary disease. Clin Chest Med. 2014;35(1):71-86.

43. Tang W, Bentley AR, Kritchevsky SB, Harris TB, Newman AB, Bauer DC, Meibohm B, Cassano PA, Health ABCs. Genetic variation in antioxidant enzymes, cigarette smoking, and longitudinal change in lung function. Free Radic Biol Med. 2013;63:304-12

44. Willey JC, Frampton MW, Utell MJ, Apostolakos MJ, Coy EL, Olson DE, Hammersley JR, Matteson D, Thilly WG. Patterns of gene expression in human airway epithelial cells. Chest. 1997;111(6 Suppl):83S.

45. DeMuth JP, Jackson CM, Weaver DA, Crawford EL, Durzinsky DS, Durham SJ, Zaher A, Phillips ER, Khuder SA, Willey JC. The gene expression index c-myc $\times$ E2F-1/p21 is highly predictive of malignant phenotype in human bronchial epithelial cells. Am J Respir Cell Mol Biol. 1998;19(1):18-24.

46. Bentley AR, Kritchevsky SB, Harris TB, Newman AB, Bauer DC, Meibohm B, Clark AG, Cassano PA, Health ABCS. Genetic variation in antioxidant enzymes and lung function. Free Radic Biol Med. 2012;52(9):1577-83.

47. Tsuji T, Aoshiba K, Nagai A. Alveolar cell senescence in patients with pulmonary emphysema. Am J Respir Crit Care Med. 2006;174(8):886-93.

48. Shaykhiev R, Sackrowitz R, Fukui T, Zuo WL, Chao IW, Strulovici-Barel Y, Downey RJ, Crystal RG. Smoking-induced CXCL14 expression in the human airway epithelium links chronic obstructive pulmonary disease to lung cancer. Am J Respir Cell Mol Biol. 2013;49(3):418-25.

49. Heijink IH, Noordhoek JA, Timens W, van Oosterhout AJ, Postma DS Abnormalities in airway epithelial junction formation in chronic obstructive pulmonary disease. Am J Respir Crit Care Med. 2014;189(11):1439-42.

50. Hersh CP, Pillai SG, Zhu G, Lomas DA, Bakke P, Gulsvik A, DeMeo DL, Klanderman BJ, Lazarus $\mathrm{R}$, Litonjua $\mathrm{AA}$, et al. Multistudy fine mapping of chromosome $2 q$ identifies XRCC5 as a chronic obstructive pulmonary disease susceptibility gene. Am J Respir Crit Care Med. 2010;182(5):605-13.

51. Miglino N, Roth M, Tamm M, Borger P. Asthma and COPD - the C/EBP connection. Open Respir Med J. 2012;6:1-13.

52. Didon L, Roos AB, Elmberger GP, Gonzalez FJ, Nord M. Lung-specific inactivation of CCAAT/enhancer binding protein alpha causes a pathological pattern characteristic of COPD. Eur Respir J. 2010;35(1):186-97.

53. Didon L, Qvarfordt I, Andersson O, Nord M, Riise GC. Decreased CCAAT/ enhancer binding protein transcription factor activity in chronic bronchitis and COPD. Chest. 2005;127(4):1341-6.

54. da Silva AL, da Rosa HT, Karnopp TE, Charlier CF, Ellwanger JH, Moura DJ, Possuelo LG, Valim AR, Guecheva TN, Henriques JA. Evaluation of DNA damage in COPD patients and its correlation with polymorphisms in repair genes. BMC Med Genet. 2013;14:93.

55. Lakhdar R, Denden S, Knani J, Leban N, Daimi H, Hassine M, Lefranc G, Chibani JB, Khelil AH. Combined analysis of EPHX1, GSTP1, GSTM1 and
GSTT1 gene polymorphisms in relation to chronic obstructive pulmonary disease risk and lung function impairment. Dis Markers. 2011;30(5):253-63.

56. He JQ, Ruan J, Connett JE, Anthonisen NR, Pare PD, Sandford AJ. Antioxidant gene polymorphisms and susceptibility to a rapid decline in lung function in smokers. Am J Respir Crit Care Med. 2002;166(3):323-8.

57. Siedlinski M, Postma DS, Boer JM, van der Steege G, Schouten JP, Smit HA, Boezen HM. Level and course of FEV1 in relation to polymorphisms in NFE2L2 and KEAP1 in the general population. Respir Res. 2009;10:73.

58. Yang SF, XU YJ, Xie JG, Zhang ZX. hOGG1 Ser326Cys and XRCC1 Arg399GIn polymorphisms associated with chronic obstructive pulmonary disease. Chin Med J. 2009;122(8):960-6.

59. Young RP, Hopkins R, Black PN, Eddy C, Wu L, Gamble GD, Mills GD, Garrett JE, Eaton TE, Rees Ml. Functional variants of antioxidant genes in smokers with COPD and in those with normal lung function. Thorax. 2006;61(5):394-9.

60. Sorheim IC, DeMeo DL, Washko G, Litonjua A, Sparrow D, Bowler R, Bakke P, Pillai SG, Coxson HO, Lomas DA, et al. Polymorphisms in the superoxide dismutase-3 gene are associated with emphysema in COPD. Copd. 2010; 7(4):262-8.

61. Korytina GF, Akhmadishina LZ, Tselousova OS, Zagidullin Sh Z, Viktorova TV. Polymorphism of the genes for antioxidant defense enzymes and their association with the development of chronic obstructive pulmonary disease in the population of Bashkortostan. Genetika. 2009;45(7):967-76.

62. Juul K, Tybjaerg-Hansen A, Marklund S, Lange P, Nordestgaard BG. Genetically increased antioxidative protection and decreased chronic obstructive pulmonary disease. Am J Respir Crit Care Med. 2006;173(8):858-64.

63. Dahl M, Bowler RP, Juul K, Crapo JD, Levy S, Nordestgaard BG. Superoxide dismutase 3 polymorphism associated with reduced lung function in two large populations. Am J Respir Crit Care Med. 2008;178(9):906-12.

64. Ganguly K, Depner M, Fattman C, Bein K, Oury TD, Wesselkamper SC, Borchers MT, Schreiber M, Gao F, von Mutius E, et al. Superoxide dismutase 3, extracellular (SOD3) variants and lung function. Physiol Genomics. 2009; 37(3):260-7

65. Bosse Y. Updates on the COPD gene list. Int J Chron Obstruct Pulmon Dis. 2012;7:607-31.

66. Arif E, Vibhuti A, Deepak D, Singh B, Siddiqui MS, Pasha MAQ. COX2 and p53 risk-alleles coexist in COPD. Clin Chim Acta. 2008;397(1-2):46-50.

67. Lee YL, Chen W, Tsai WK, Lee JC, Chiou HL, Shih CM, Wang YC. Polymorphisms of p53 and p21 genes in chronic obstructive pulmonary disease. J Lab Clin Med. 2006;147(5):228-33.

68. Hua CC, Chang LC, Tseng JC, Chu CM, Liu YC, Shieh WB. Functional haplotypes in the promoter region of transcription factor Nrf2 in chronic obstructive pulmonary disease. Dis Markers. 2010;28(3):185-93.

69. Yan F, Chen C, Jing J, Li W, Shen H, Wang X. Association between polymorphism of glutathione S-transferase P1 and chronic obstructive pulmonary disease: a meta-analysis. Respir Med. 2010;104(4):473-80.

70. Mori M, Bjermer L, Erjefalt JS, Stampfli MR, Roos AB. Small airway epithelial-C/ EBPbeta is increased in patients with advanced COPD. Respir Res. 2015:16:133.

71. Timchenko NA, Harris TE, Wilde M, Bilyeu TA, Burgess-Beusse BL, Finegold MJ, Darlington GJ. CCAAT/enhancer binding protein alpha regulates p21 protein and hepatocyte proliferation in newborn mice. Mol Cell Biol. 1997; 17(12):7353-61.

72. Timchenko NA, Wilde M, Nakanishi M, Smith JR, Darlington GJ. CCAAT/ enhancer-binding protein alpha (C/EBP alpha) inhibits cell proliferation through the p21 (WAF-1/CIP-1/SDI-1) protein. Genes Dev. 1996;10(7):804-15.

73. Ramji DP, Foka P. CCAAT/enhancer-binding proteins: structure, function and regulation. Biochem J. 2002;365(Pt 3):561-75.

74. Eaton EM, Hanlon M, Bundy L, Sealy L. Characterization of C/EBPbeta isoforms in normal versus neoplastic mammary epithelial cells. J Cell Physiol. 2001;189(1):91-105.

75. O'Rourke JP, Hutt JA, DeWille J. Transcriptional regulation of C/EBPdelta in $\mathrm{G}(0)$ growth-arrested mouse mammary epithelial cells. Biochem Biophys Res Commun. 1999:262(3):696-701.

76. Kaisho T, Tsutsui H, Tanaka T, Tsujimura T, Takeda K, Kawai T, Yoshida N, Nakanishi K, Akira S. Impairment of natural killer cytotoxic activity and interferon gamma production in CCAAT/enhancer binding protein gammadeficient mice. J Exp Med. 1999;190(11):1573-82.

77. Korytina GF, Akhmadishina LZ, Kochetova OV, Burdiuk lu V, Aznabaeva lu G, Zagidullin Sh Z, Victorova TV. Association of the nicotine and cigarette smoke toxicants metabolic (CHRNA3/5, CYP2A6, NQO1) and DNA repair genes (XRCC1, XRCC3, XPC, XPA) with chronic obstructive pulmonary disease. Mol Biol. 2014;48(6):939-51. 
78. Parkin SE, Baer M, Copeland TD, Schwartz RC, Johnson PF. Regulation of CCAAT/ enhancer-binding protein (C/EBP) activator proteins by heterodimerization with C/EBPgamma (lg/EBP). J Biol Chem. 2002;277(26):23563-72.

79. Tuder RM, Yun JH, Graham BB. Cigarette smoke triggers code red: p21CIP1/ WAF1/SDI1 switches on danger responses in the lung. Am J Respir Cell Mol Biol. 2008;39(1):1-6.

80. Warner SM, Hackett TL, Shaheen F, Hallstrand TS, Kicic A, Stick SM, Knight DA. Transcription factor p63 regulates key genes and wound repair in human airway epithelial basal cells. Am J Respir Cell Mol Biol. 2013;49(6): 978-88.

81. Daniely Y, Liao G, Dixon D, Linnoila Rl, Lori A, Randell SH, Oren M, Jetten AM. Critical role of p63 in the development of a normal esophageal and tracheobronchial epithelium. Am J Physiol Cell Physiol. 2004;287(1):C171-81.

82. Hong KU, Reynolds SD, Watkins S, Fuchs E, Stripp BR. In vivo differentiation potential of tracheal basal cells: evidence for multipotent and unipotent subpopulations. Am j physiol Lung cell mol physiol. 2004;286(4):L643-9.

83. Hong KU, Reynolds SD, Watkins S, Fuchs E, Stripp BR. Basal cells are a multipotent progenitor capable of renewing the bronchial epithelium. Am J Pathol. 2004;164(2):577-88.

84. Koster MI, Kim S, Mills AA, DeMayo FJ, Roop DR. p63 is the molecular switch for initiation of an epithelial stratification program. Genes Dev. 2004;18(2):126-31.

85. Romano RA, Smalley K, Magraw C, Serna VA, Kurita T, Raghavan S, Sinha S. DeltaNp63 knockout mice reveal its indispensable role as a master regulator of epithelial development and differentiation. Development. 2012;139(4):772-82.

86. Candi E, Cipollone R, Rivetti di Val Cervo P, Gonfloni S, Melino G, Knight R. p63 in epithelial development. Cell Mol Life Sci. 2008;65(20):3126-33.

87. Mills AA, Zheng B, Wang XJ, Vogel H, Roop DR, Bradley A. p63 is a p53 homologue required for limb and epidermal morphogenesis. Nature. 1999; 398(6729):708-13.

88. Yang A, Schweitzer R, Sun D, Kaghad M, Walker N, Bronson RT, Tabin C, Sharpe A, Caput D, Crum C, et al. p63 is essential for regenerative proliferation in limb, craniofacial and epithelial development. Nature. 1999; 398(6729):714-8.

89. Arason AJ, Jonsdottir HR, Halldorsson S, Benediktsdottir BE, Bergthorsson JT, Ingthorsson S, Baldursson O, Sinha S, Gudjonsson T, Magnusson MK. deltaNp63 has a role in maintaining epithelial integrity in airway epithelium. PLoS One. 2014;9(2):e88683.

90. Marshall CB, Mays DJ, Beeler JS, Rosenbluth JM, Boyd KL, Santos Guasch GL, Shaver TM, Tang LJ, Liu Q, Shyr Y, et al. p73 is required for Multiciliogenesis and regulates the Foxj1-associated gene network. Cell Rep. 2016;14(10): 2289-300.

91. Crawford EL, Levin A, Safi F, Lu M, Baugh A, Zhang X, Yeo J, Khuder SA, Boulos AM, Nana-Sinkam P, et al. Lung cancer risk test trial: study design, participant baseline characteristics, bronchoscopy safety, and establishment of a biospecimen repository. BMC pulm med. 2016;16:16.

92. Vestbo J, Hurd SS, Agusti AG, Jones PW, Vogelmeier C, Anzueto A, Barnes PJ, Fabbri LM, Martinez FJ, Nishimura M, et al. Global strategy for the diagnosis, management, and prevention of chronic obstructive pulmonary disease: GOLD executive summary. Am J Respir Crit Care Med. 2013;187(4):347-65.

93. Zhang X, Crawford EL, Blomquist TM, Khuder SA, Yeo J, Levin AM, Willey JC. Haplotype and diplotype analyses of variation in ERCC5 transcription cis-regulation in normal bronchial epithelial cells. Physiol Genomics. 2016;48(7):537-43.

94. Vermeulen J, De Preter K, Lefever S, Nuytens J, De Vloed F, Derveaux S, Hellemans J, Speleman F, Vandesompele J. Measurable impact of RNA quality on gene expression results from quantitative PCR. Nucleic Acids Res. 2011;39(9):e63.

95. Kusko RL, Brothers JF 2nd, Tedrow J, Pandit K, Huleihel L, Perdomo C, Liu G, Juan-Guardela B, Kass D, Zhang S, et al. Integrated genomics reveals convergent transcriptomic networks underlying chronic obstructive pulmonary disease and idiopathic pulmonary fibrosis. Am J Respir Crit Care Med. 2016;194(8):948-60

96. Sudmant PH, Rausch T, Gardner EJ, Handsaker RE, Abyzov A, Huddleston J, Zhang Y, Ye K, Jun G, Hsi-Yang Fritz M, et al. An integrated map of structural variation in 2,504 human genomes. Nature. 2015;526(7571):75-81.

97. Pastinen T, Sladek R, Gurd S, Sammak A, Ge B, Lepage P, Lavergne K, Villeneuve A, Gaudin T, Brandstrom H, et al. A survey of genetic and epigenetic variation affecting human gene expression. Physiol Genomics. 2004;16(2):184-93.

98. Regan EA, Hokanson JE, Murphy JR, Make B, Lynch DA, Beaty TH, CurranEverett D, Silverman EK, Crapo JD. Genetic epidemiology of COPD (COPDGene) study design. Copd. 2010;7(1):32-43.
99. Connett JE, Kusek JW, Bailey WC, O'Hara P, Wu M. Design of the Lung Health Study: a randomized clinical trial of early intervention for chronic obstructive pulmonary disease. Control Clin Trials. 1993;14(2 Suppl):3s-19s.

100. Ahdesmaki M, Strimmer K. Feature selection in omics prediction problems using cat scores and false nondiscovery rate control. Ann Appl Stat. 2010; 4(1):503-19.

101. Ge B, Pokholok DK, Kwan T, Grundberg E, Morcos L, Verlaan DJ, Le J, Koka V, Lam KC, Gagne V, et al. Global patterns of cis variation in human cells revealed by high-density allelic expression analysis. Nat Genet. 2009;41(11): 1216-22.

102. Campbell I. Chi-squared and Fisher-Irwin tests of two-by-two tables with small sample recommendations. Stat Med. 2007;26(19):3661-75.

103. Liu C, Zhang F, Li T, Lu M, Wang L, Yue W, Zhang D. MirSNP, a database of polymorphisms altering miRNA target sites, identifies miRNA-related SNPs in GWAS SNPs and eQTLs. BMC Genomics. 2012;13:661.

104. Consortium GT. The genotype-tissue expression (GTEx) pilot analysis: multitissue gene regulation in humans. Science. 2015;348(6235):648-60.

105. Rosenbloom KR, Armstrong J, Barber GP, Casper J, Clawson H, Diekhans M, Dreszer TR, Fujita PA, Guruvadoo L, Haeussler M, et al. The UCSC genome browser database: 2015 update. Nucleic Acids Res. 2015;43(Database issue): D670-81.

106. Zhu ML, Shi TY, Hu HC, He J, Wang M, Jin L, Yang YJ, Wang JC, Sun MH, Chen $\mathrm{H}$, et al. Polymorphisms in the ERCC5 gene and risk of esophageal squamous cell carcinoma (ESCC) in eastern Chinese populations. PLoS One. 2012;7(7):e41500.

107. Boyle AP, Hong EL, Hariharan M, Cheng Y, Schaub MA, Kasowski M, Karczewsk KJ, Park J, Hitz BC, Weng S, et al. Annotation of functional variation in personal genomes using RegulomeDB. Genome Res. 2012;22(9):1790-7.

108. Dimas AS, Deutsch S, Stranger BE, Montgomery SB, Borel C, Attar-Cohen H, Ingle C, Beazley C, Gutierrez Arcelus M, Sekowska M, et al. Common regulatory variation impacts gene expression in a cell type-dependent manner. Science. 2009;325(5945):1246-50.

109. Fairfax BP, Makino S, Radhakrishnan J, Plant K, Leslie S, Dilthey A, Ellis P, Langford C, Vannberg FO, Knight JC. Genetics of gene expression in primary immune cells identifies cell type-specific master regulators and roles of HLA alleles. Nat Genet. 2012;44(5):502-10.

110. Melnikov A, Murugan A, Zhang X, Tesileanu T, Wang L, Rogov P, Feizi S, Gnirke A, Callan CG Jr, Kinney JB, et al. Systematic dissection and optimization of inducible enhancers in human cells using a massively parallel reporter assay. Nat Biotechnol. 2012;30(3):271-7.

111. Kwasnieski JC, Mogno I, Myers CA, Corbo JC, Cohen BA. Complex effects of nucleotide variants in a mammalian cis-regulatory element. Proc Natl Acad Sci U S A. 2012;109(47):19498-503.

112. White MA, Myers CA, Corbo JC, Cohen BA. Massively parallel in vivo enhancer assay reveals that highly local features determine the cisregulatory function of ChIP-seq peaks. Proc Natl Acad Sci U S A. 2013; 110(29):11952-7.

\section{Submit your next manuscript to BioMed Central and we will help you at every step:}

- We accept pre-submission inquiries

- Our selector tool helps you to find the most relevant journal

- We provide round the clock customer support

- Convenient online submission

- Thorough peer review

- Inclusion in PubMed and all major indexing services

- Maximum visibility for your research

Submit your manuscript at www.biomedcentral.com/submit 